\title{
EDITORIAL: NOVOS RUMOS E CONTINUIDADES NA PESQUISA E PUBLICAÇÃO EM CIÊNCIA POLÍTICA
}

Ao assumir, para dar continuidade ao trabalho de publicização da produção acadêmica em Ciência Política a que se propõe a RECP, a atual equipe editorial se deparou, neste ano de 2013, com uma série de trabalhos submetidos em seu sistema. Verificou-se, então, que alguns desses trabalhos eram de boa qualidade científica e pertinentes ao campo, sendo injusto, para os autores e para a comunidade, mantê-los sem divulgação. Assim, realizou-se um intenso trabalho de análise, seleção e contato com os autores, visando possíveis, necessárias e pontuais alterações. Passado esse processo, temos orgulho em apresentar uma edição retroativa de 2012, com os melhores artigos recebidos ao longo de 2011 e 2012.

Esta edição é composta pelos artigos seguintes. $A$ judicialização $d a$ política no Brasil: uma análise das ADINS nos governos FHC e Lula, de Gabriella Maria Lima Bezerra. Este estudo traz uma importante contribuição aos estudos de política e judiciário, ao revelar o perfil da judicialização da política no âmbito federal brasileiro, tendo por base os governos de FHC e Lula. O segundo artigo, A participação da sociedade civil nas instituições comunitárias do MERCOSUL (1991 - 2010), de Ludmila Andrzejewski Culpi, analisa a participação da sociedade civil num contexto de institucionalização do bloco, representado, sobretudo, pelo Foro Consultivo Econômico-Social e pelo Parlamento do MERCOSUL. O terceiro texto, Remanejamento da população atingida por usinas hidrelétricas como política pública, dos pesquisadores Hemerson Luiz Pase, Matheus Müller e Jennifer Azambuja de Morais, apresenta uma análise de políticas públicas, destacando o papel do Estado em políticas que envolvem entes privados, no remanejamento de populações atingidas pela instalação de hidroelétricas. Segue, então, o texto Fundamentação teórica da integração regional e sua importância para os $P E D$, de Lito Nunes Fernandes, que trata da integração regional dos Países em Desenvolvimento como estratégia de solução de vários problemas, como sustentabilidade socioeconômica e estabilidade política. A edição é encerrada com o artigo de viés metodológico dos pesquisadores Dalson Britto Figueiredo 


\title{
Editorial
}

Filho, Ranulfo Paranhos, Enivaldo Carvalho da Rocha, José Alexandre da Silva Jr. e Manoel Leonardo Wanderley Duarte Santos. Levando Gary King a sério: desenhos de pesquisa em Ciência Política, apresenta procedimentos para auxiliar o pesquisador no seu desenho de pesquisa. Trata-se de um texto que vem ao encontro das aspirações do campo e do perfil editorial que a RECP assume. Visa a ser um trabalho que traga contribuições para pesquisadores em Ciência Política, de forma objetiva, mas sem que se perca em profundidade.

Espera-se, com esta edição, dar continuidade, sem interrupções, ao trabalho iniciado pela RECP no ano de 2010. Agradecemos ao esforço dos pesquisadores, que vêm transformando o campo da Ciência Política nas últimas décadas, destacando sua importância para as ciências sociais e para a compreensão do mundo contemporâneo. Por fim, convidamos nosso caro leitor a conhecer o trabalho dos pesquisadores que, orgulhosamente, apresentamos nesta edição.

Boa leitura.

\author{
José Augusto Hartmann \\ Márcio Cunha Carlomagno \\ Editores-executivos
}

